\title{
Central Arctic Caribou and Petroleum Development: Distributional, Nutritional, and Reproductive Implications
}

\author{
RAYMOND D. CAMERON, ${ }^{1,2}$ WALTER T. SMITH, ${ }^{1}$ ROBERT G. WHITE ${ }^{3}$ and BRAD GRIFFITH ${ }^{4}$
}

\author{
(Received 15 October 2002; accepted in revised form 11 May 2004)
}

\begin{abstract}
We synthesize findings from cooperative research on effects of petroleum development on caribou (Rangifer tarandus granti) of the Central Arctic Herd (CAH). The CAH increased from about 6000 animals in 1978 to 23000 in 1992 , declined to 18000 by 1995, and again increased to 27000 by 2000. Net calf production was consistent with changes in herd size. In the Kuparuk Development Area (KDA), west of Prudhoe Bay, abundance of calving caribou was less than expected within $4 \mathrm{~km}$ of roads and declined exponentially with road density. With increasing infrastructure, high-density calving shifted from the KDA to inland areas with lower forage biomass. During July and early August, caribou were relatively unsuccessful in crossing road/pipeline corridors in the KDA, particularly when in large, insect-harassed aggregations; and both abundance and movements of females were lower in the oil field complex at Prudhoe Bay than in other areas along the Arctic coast. Female caribou exposed to petroleum development west of the Sagavanirktok River may have consumed less forage during the calving period and experienced lower energy balance during the midsummer insect season than those under disturbance-free conditions east of the river. The probable consequences were poorer body condition at breeding and lower parturition rates for western females than for eastern females (e.g., 1988-94: 64\% vs. 83\% parturient, respectively; $p=0.003$ ), which depressed the productivity of the herd. Assessments of cumulative effects of petroleum development on caribou must incorporate the complex interactions with a variable natural environment.
\end{abstract}

Key words: behavior, body condition, calving, cumulative effects, demography, fecundity, habitat, Rangifer

RÉSUMÉ. On a procédé à une synthèse des résultats de travaux de recherche coopérative concernant les effets de l'exploitation pétrolière sur le caribou (Rangifer tarandus granti) formant la harde du centre de l'Arctique (HCA). La population de celle-ci est passée de 6000 têtes en 1978 à 23000 en 1992, puis a diminué à 18000 en 1995 pour augmenter de nouveau à 27000 en 2000. La production nette des veaux allait de pair avec les changements dans la taille de la harde. Dans la zone de développement de Kuparuk (KDA), située à l'ouest de Prudhoe Bay, l'abondance des caribous qui mettaient bas était inférieure à celle prévue dans une bande de $4 \mathrm{~km}$ de part et d'autre des routes, et elle déclinait de façon exponentielle avec la densité routière. Avec une augmentation des infrastructures, on assistait à un déplacement du vêlage à forte densité de la KDA vers des zones de l'intérieur ayant une biomasse de fourrage moins importante. Durant juillet et au début d'août, il était assez rare que les caribous réussissent à traverser les corridors routiers/pipeliniers dans la KDA, surtout lorsqu'ils formaient de vastes agrégations harcelées par les insectes; l'abondance de même que les déplacements des femelles étaient en outre moindres au sein du complexe pétrolier de Prudhoe Bay qu'à d'autres endroits situés le long du rivage arctique. Il est possible que les femelles qui étaient exposées à l'exploitation pétrolière à l'ouest de la rivière Sagavanirktok aient consommé moins de fourrage au cours de la période de vêlage et que, durant la saison des insectes au milieu de l'été, elles aient connu une balance énergétique inférieure à celle des femelles vivant sans perturbations à l'est de la rivière. Les conséquences probables étaient un état corporel de qualité inférieure au moment de l'accouplement, et des taux de parturition plus faibles pour les femelles situées à l'ouest que pour celles situées à l'est (p. ex., de 1988 à 1994: $64 \%$ c. $83 \%$ de parturientes respectivement: $p=0,003$ ), faisant ainsi baisser la productivité de la harde. Les évaluations des effets cumulatifs de l'exploitation pétrolière sur le caribou doivent intégrer les interactions complexes avec un environnement naturel variable.

Mots clés: comportements, état corporel, vêlage, effets cumulatifs, démographie, fécondité, habitat, Rangifer

Traduit pour la revue Arctic par Nésida Loyer.

\footnotetext{
${ }^{1}$ Alaska Department of Fish and Game, 1300 College Road, Fairbanks, Alaska 99701-1599, U.S.A.

${ }^{2}$ Present address: Institute of Arctic Biology, University of Alaska Fairbanks, Fairbanks, Alaska 99775, U.S.A.; ffrdc@uaf.edu

${ }^{3}$ Institute of Arctic Biology, University of Alaska Fairbanks, Fairbanks, Alaska 99775, U.S.A.

${ }^{4}$ USGS Alaska Cooperative Fish and Wildlife Research Unit, University of Alaska Fairbanks, Fairbanks, Alaska 99775, U.S.A.

(C) The Arctic Institute of North America
} 


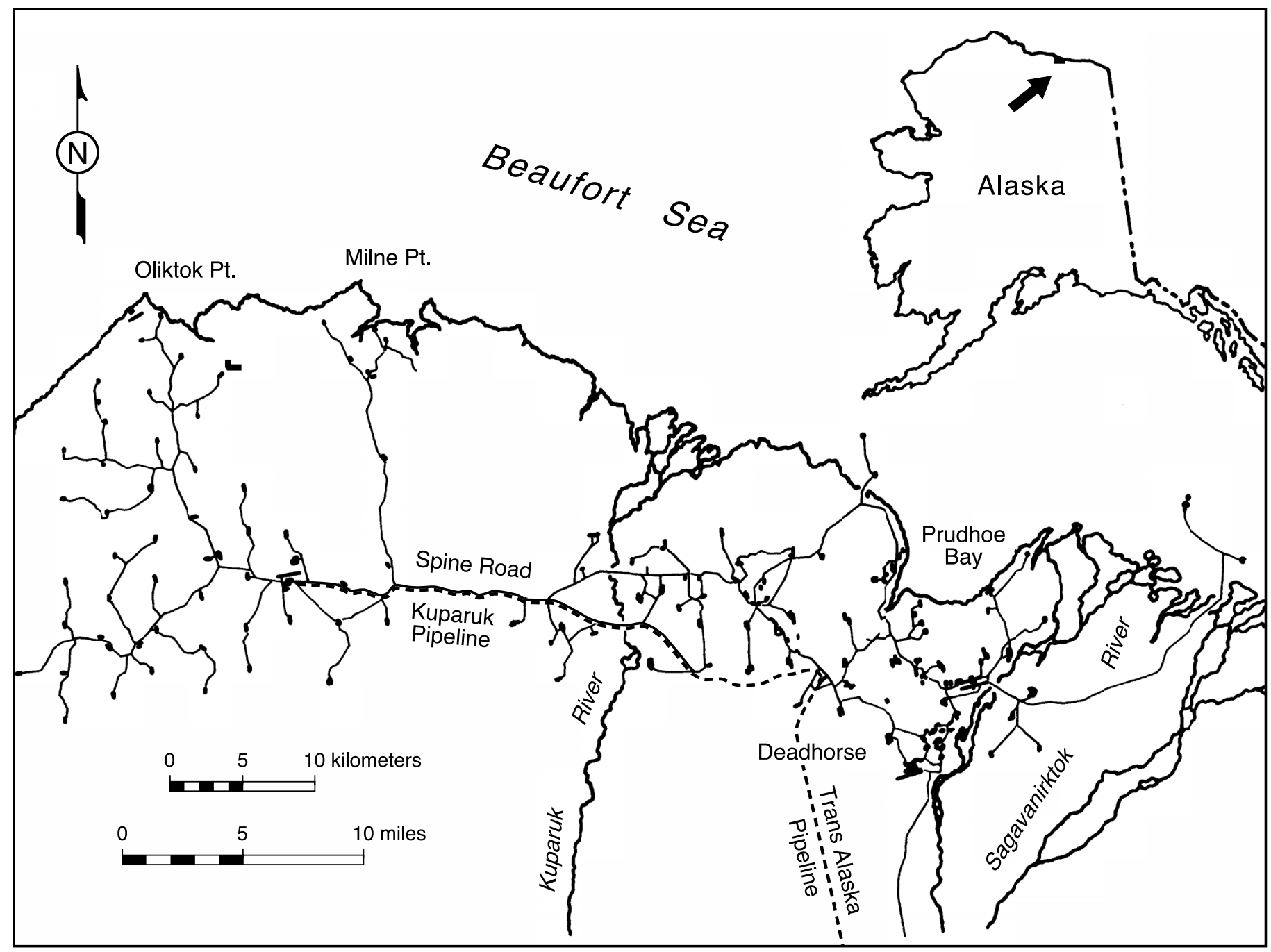

FIG. 1. Roads and facilities in the Kuparuk Development Area (west of the Kuparuk River) and Prudhoe Bay oil field complex (east of the Kuparuk River), Alaska, ca. 1990 (Cameron et al., 1995; reprinted with permission from Rangifer).

\section{INTRODUCTION}

From the mid-1970s through the mid-1980s, use of calving and midsummer habitats by Central Arctic Herd (CAH) caribou (Rangifer tarandus granti) declined near oil field infrastructure on Alaska's Arctic Coastal Plain (Cameron et al., 1979; Cameron and Whitten, 1980; Smith and Cameron, 1983; Whitten and Cameron, 1983a, 1985; Dau and Cameron, 1986). With surface development continuing to expand westward from the Prudhoe Bay oil field complex (Fig. 1), concerns arose that the resultant cumulative losses of habitat would eventually reduce productivity of the herd. Specifically, reduced access of adult females to preferred foraging areas might adversely affect growth and fattening (Elison et al., 1986; Clough et al., 1987), in turn depressing calf production (Dauphiné, 1976; Thomas, 1982; Reimers, 1983; White, 1983; Eloranta and Nieminen, 1986; Lenvik et al., 1988; Thomas and Kiliaan, 1998) and calf survival (Haukioja and Salovaara, 1978; Rognmo et al., 1983; Skogland, 1984; Eloranta and Nieminen, 1986; Adamczewski et al., 1987).
Those concerns, though justified in theory, lacked empirical support. With industrial development in Arctic Alaska virtually unprecedented, there was little basis for predicting the extent and duration of habitat loss, much less the secondary short- and long-term effects on the wellbeing of a particular caribou herd. Furthermore, despite a general acceptance that body condition and fecundity of females are functionally related for reindeer (R.t.tarandus) and caribou, it seemed unlikely that any single model would apply to all subspecies of Rangifer, or even within a subspecies, to all geographic regions. We therefore lacked a complete understanding of the behavioral responses of Arctic caribou to industrial development, the manner in which access to various habitats might be affected, and how changes in habitat use might translate into effects on fecundity and herd growth.

Our studies had four objectives: 1) to estimate variation in the size and productivity of the $\mathrm{CAH}$; 2) to estimate changes in the distribution and movements of $\mathrm{CAH}$ caribou in relation to oil field development; 3 ) to estimate the relationships between body condition and reproductive 

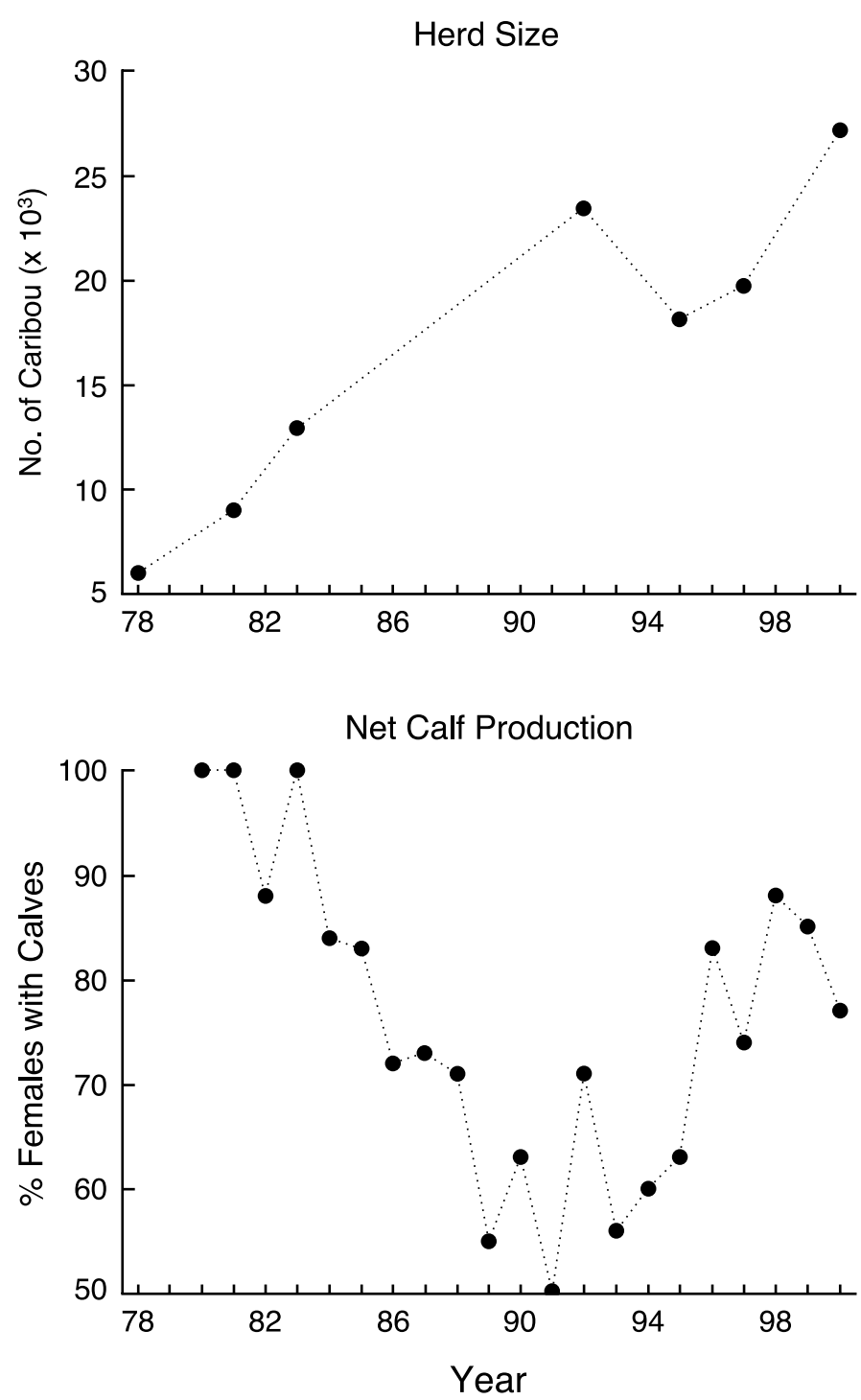

FIG. 2. Photo-census estimates of the Central Arctic caribou herd, 1978-2000 (Whitten and Cameron, 1983b; Alaska Department of Fish and Game files) and net calf production based on observations of radio-collared adult (i.e., sexually mature) females from 10 June through 15 August (Alaska Department of Fish and Game files). Note: Productivity data are not adjusted for differences in sample sizes east and west of the Sagavanirktok River.

performance of female CAH caribou; and 4) to compare the body condition and reproductive success of females under disturbance-free conditions (i.e., east of the Sagavanirktok River) with the status of those exposed to petroleum-related development (i.e., west of the Sagavanirktok River) (Fig. 1).

\section{Status of the Central Arctic Herd}

Photocensus results indicate net growth of the CAH from 1978 through 2000 (Fig. 2). Within that long-term trend, however, was a decrease from 1992 to 1995, which coincided with calf production estimates at or below approximately $70 \%$. Calf production was also relatively low during 1989-91, suggesting that herd growth had decelerated or ceased before the 1992 census. Otherwise, periods

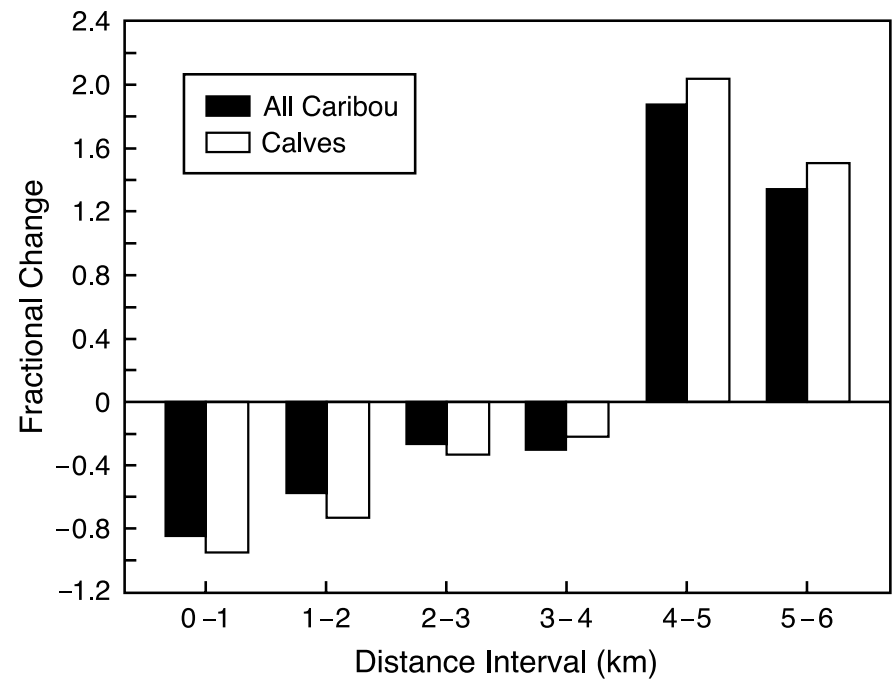

FIG. 3. Changes in mean density of calving caribou from the Central Arctic Herd from 1978-81 (before road construction) to 1982-87 (after road construction) at distances of $0-6 \mathrm{~km}$ (in $1 \mathrm{~km}$ intervals) from the Milne Point road system, Kuparuk Development Area, Alaska (Cameron et al., 1992b; reprinted with permission from Arctic).

of apparent growth were associated with productivity estimates exceeding $70 \%$.

\section{Development-Related Changes in Distribution}

Because the CAH is in contact with industrial development from calving time through midsummer, our surveys focused on those two intervals. The calving period is the three-week interval beginning with the peak of calving, i.e., after $50 \%$ of the calving has occurred (Russell et al., 2002:31); for the CAH, this peak usually occurs in early June (Cameron et al., 1993). The summer insect season follows, generally extending from late June through early August (White et al., 1975; Dau, 1986).

Changes in the distribution of calving caribou associated with the Kuparuk Development Area (KDA), west of the Kuparuk River (Fig. 1), were quantified by means of strip-transect surveys conducted from a helicopter. After construction of a road system between Milne Point and the Spine Road (Fig. 1), mean caribou abundance declined by more than two-thirds within $2 \mathrm{~km}$ of roads and was less than expected, overall, within $4 \mathrm{~km}$, but nearly doubled 4-6 km from roads (Fig. 3). Before road construction, caribou were found in a single, more or less continuous concentration that encompassed the area where roads would subsequently be built. After road construction, a bimodal distribution was clearly apparent, with separate concentrations to the west and east of the road (Fig. 4), indicating avoidance of infrastructure by calving caribou.

These results suggest that roads spaced too closely will depress calving activity within portions of an oil field complex. In fact, relative abundance of caribou in the heavily developed western portion of the KDA showed a significant decline from 1979 through 1987, which was independent of total abundance (Fig. 5). Such declines 


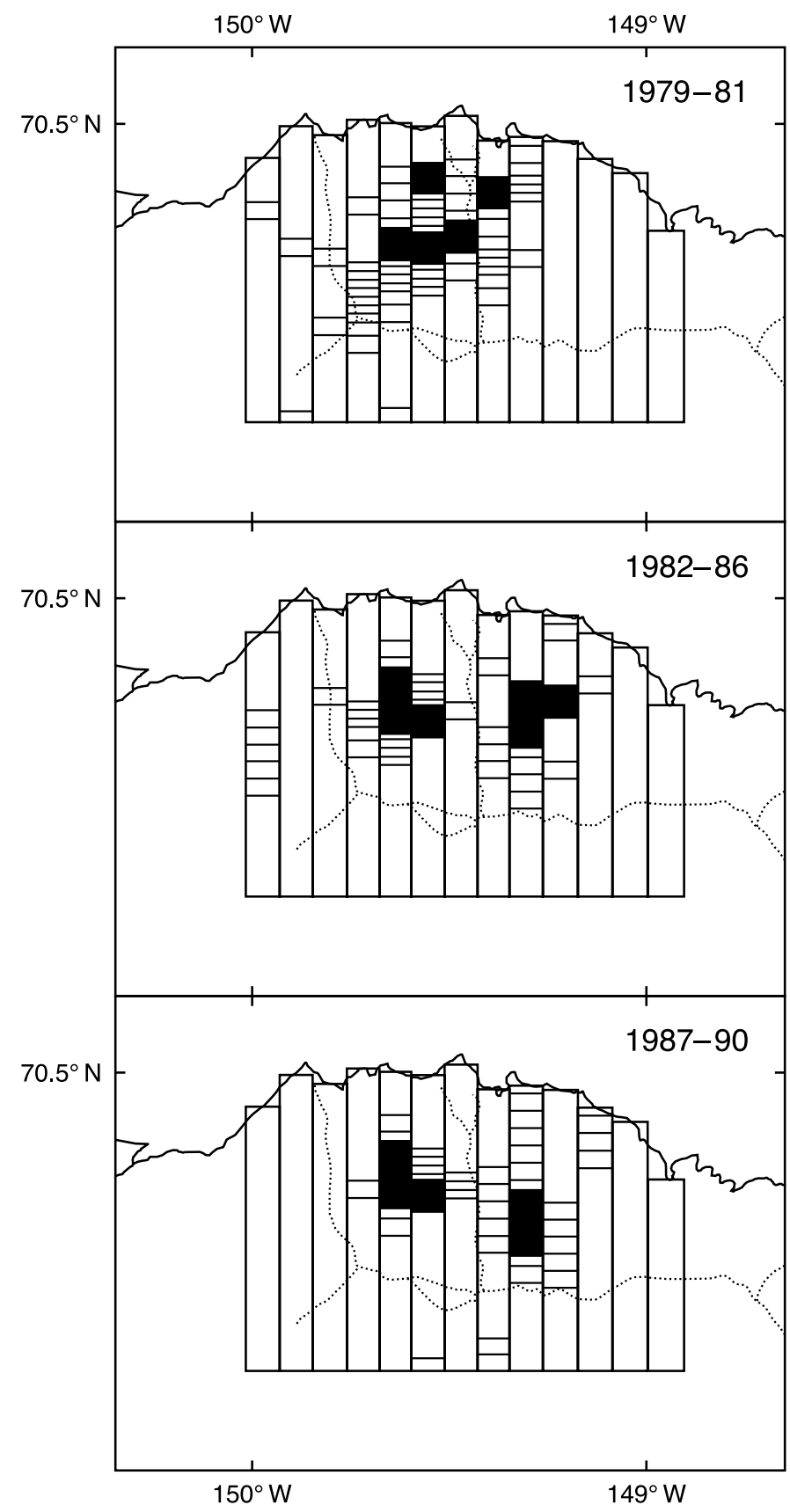

FIG. 4. Changes in mean relative distribution of caribou from the Central Arctic Herd in the Kuparuk Development Area, Alaska, during calving in 1979-81, 1982-86, and 1987-90. Each transect segment was $10.4 \mathrm{~km}^{2}$, or $0.9 \%$ of the $1150 \mathrm{~km}^{2}$ surveyed. Only those segments with more than $0.9 \%$ of the total caribou observed are shown. Gradations in line spacing depict caribou densities as multiples of the base density derived from that percentage: wide spacing = less than $3 \times$ base; narrow spacing $=3-5 \times$ base; solid $=$ more than $5 \times$ base (Smith and Cameron, 1992; reprinted with permission).

apparently involve an exponential decrease in caribou density with increasing road density (Fig. 6). The probable consequence is reduced access to preferred foraging habitats (Nellemann and Cameron, 1996, 1998).

Incremental redistribution and local habitat loss within the KDA may have triggered changes on a regional scale. Wolfe (2000) reported an inland shift of concentrated calving
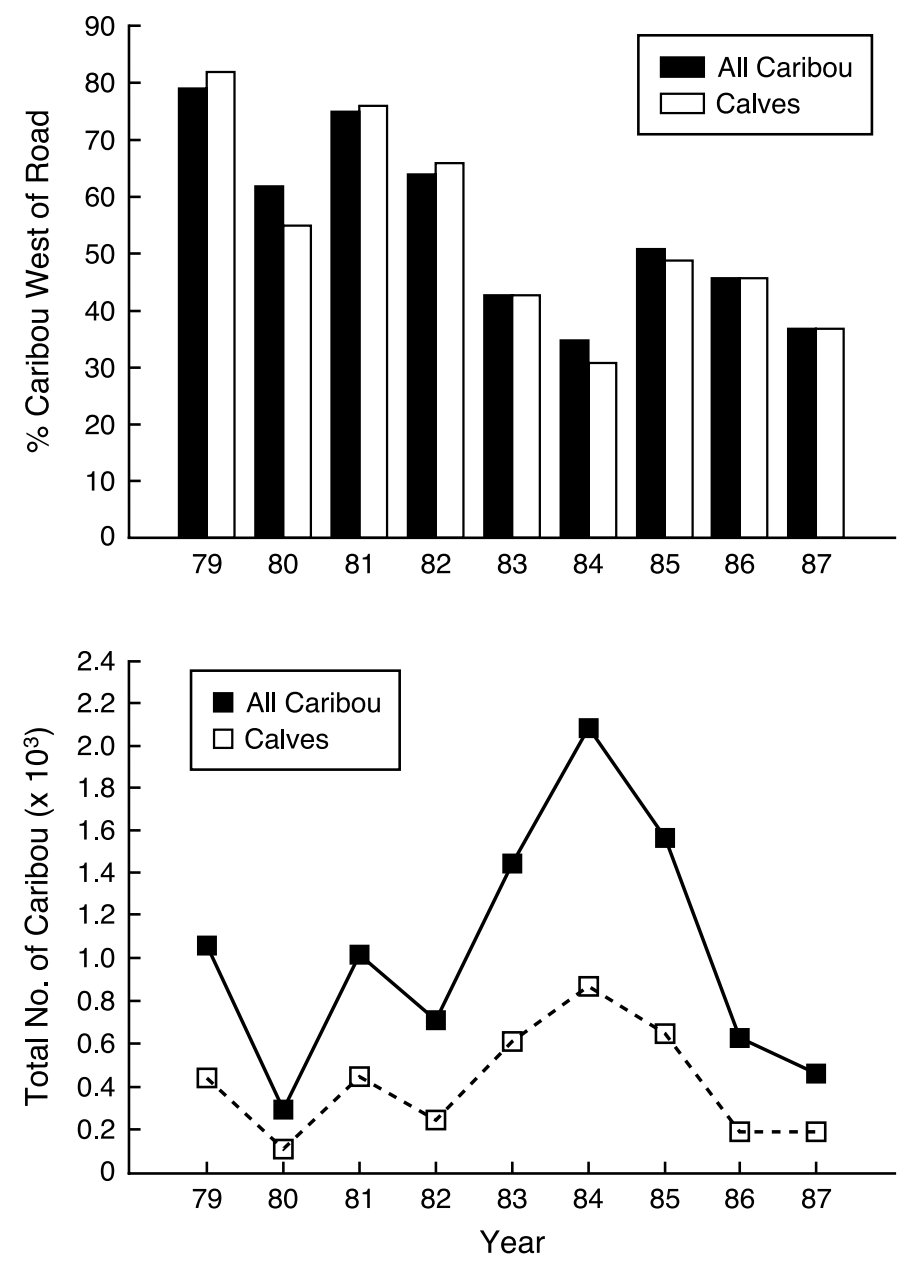

FIG. 5. Histogram shows decline in abundance of calving caribou from the Central Arctic Herd west of the Milne Point road system, Alaska, 1979-87 (Spearman's Rank, $p<0.02$ ). Abundance is expressed as a percentage of the total numbers of caribou north of the Spine Road (see Fig. 1), shown in the line graph below (Cameron et al., 1992b; reprinted with permission from Arctic).

activity away from the Milne Point area (Fig. 7), which coincided with an increase in the density of infrastructure.

Ground observations within the KDA provided additional insights on changing distribution and movements. During 1978-90, observations that caribou increasingly avoided zones of intensive construction and productionrelated activity, especially during the calving period (Smith et al., 1994), corroborated data from strip-transect surveys. Lower success in crossing road/pipeline corridors by large, insect-harassed groups during summer (Smith and Cameron, 1985; Curatolo and Murphy, 1986; Murphy and Curatolo, 1987; Murphy, 1988) may have contributed to relatively greater use of peripheral areas with less surface development and human activity. Primary routes of summer movement have shifted to areas south of Oliktok Point and along the Kuparuk River floodplain (Smith et al., 1994).

An analysis of the summer distribution of radio-collared females during 1980-93 (Cameron et al., 1995) suggested that caribou use of the oil field region at Prudhoe Bay had declined considerably from that noted by Child 


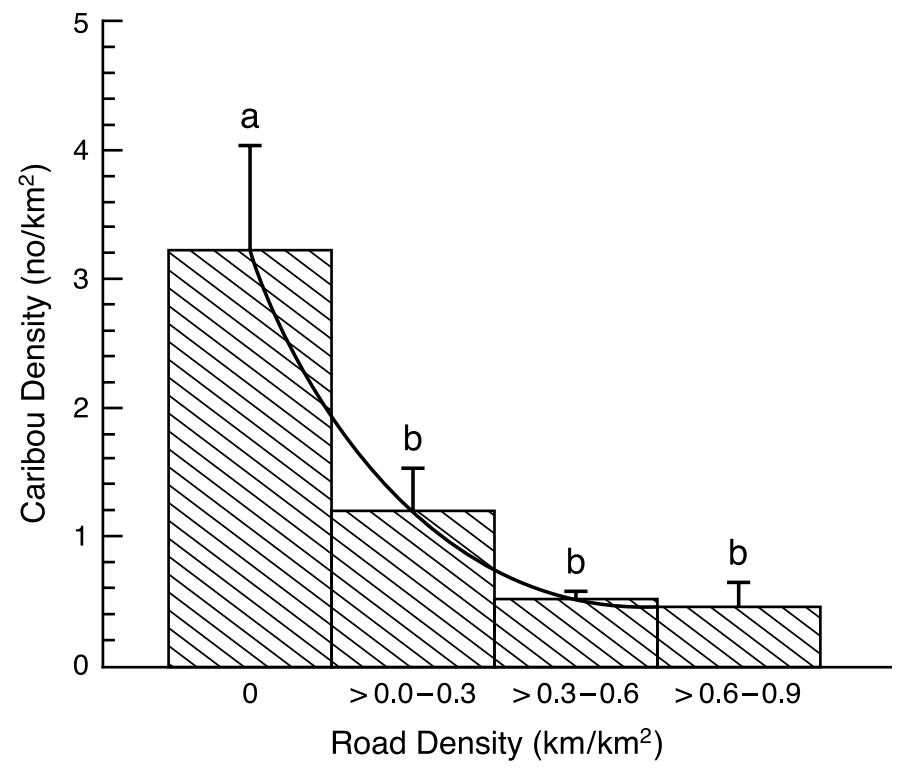

FIG. 6. Relationship between mean (SE) density of calving caribou from the Central Arctic Herd and road density within preferred rugged terrain, Kuparuk Development Area, Alaska, 1987-92. Different letters indicate a significant difference $(p<0.05)$ (Nellemann and Cameron, 1998; reprinted with permission from the Canadian Journal of Zoology).

(1973), and White et al. (1975) during the 1970s. Both caribou abundance within the main industrial complex and east-west caribou movements through that area were significantly lower $(p<0.001)$ than in other areas occupied by caribou along the Arctic coast. Conservative calculations yielded an estimated $78 \%$ decrease in use by caribou and a 90\% decrease in their east-west movements (Cameron et al., 1995), changes apparently in response to intensive development of that region over the past three decades. However, the occurrence of caribou that $d o$ use the complex during summer is reportedly unrelated to distance from infrastructure (Cronin et al., 1998).

\section{Body Condition and Reproductive Performance}

Reproductive success of caribou is highly correlated with nutritional status. The probability of producing a calf varies directly with both body weight and body fat content of sexually mature females during the previous autumn (Cameron et al., 1993, 2000; Cameron and Ver Hoef, 1994; Gerhart et al., 1997). In contrast, calving date and perinatal survival are more closely related to maternal weight shortly after parturition (i.e., estimated prepartum body weight minus weight of fetal tissues) (Fig. 8). Thus, the likelihood of conceiving is probably determined by body condition at breeding, whereas parturition date and calf survival may reflect maternal condition during late gestation.

In theory, these relationships link the nutritional consequences of changes in distribution to the reproductive success of caribou of the CAH. West of the Sagavanirktok River, caribou had reduced access to preferred foraging habitats near roads (Nellemann and Cameron, 1996) and
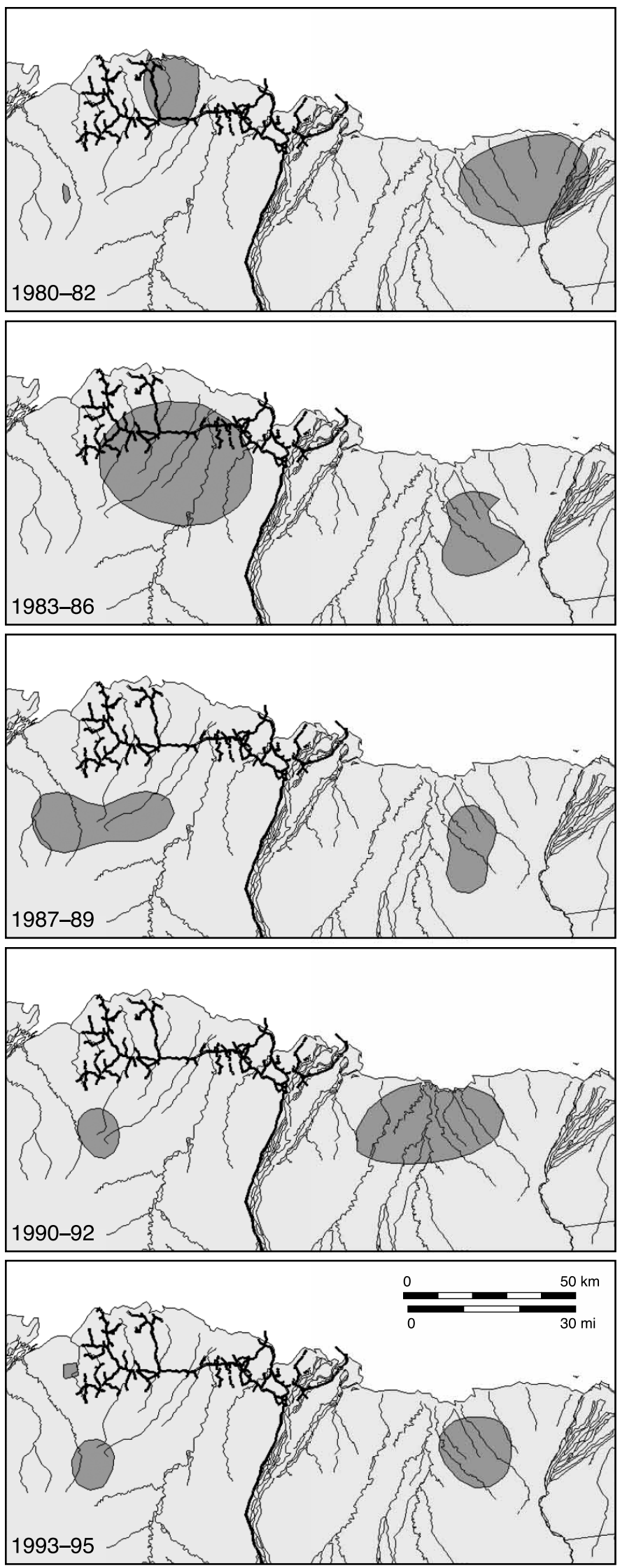

FIG. 7. Shifts in concentrated caribou calving areas of the Central Arctic Herd between the Colville and Canning rivers (note oil field infrastructure, Fig. 1), Alaska, 1980-95 (adapted from Wolfe, 2000: Fig. 3). 

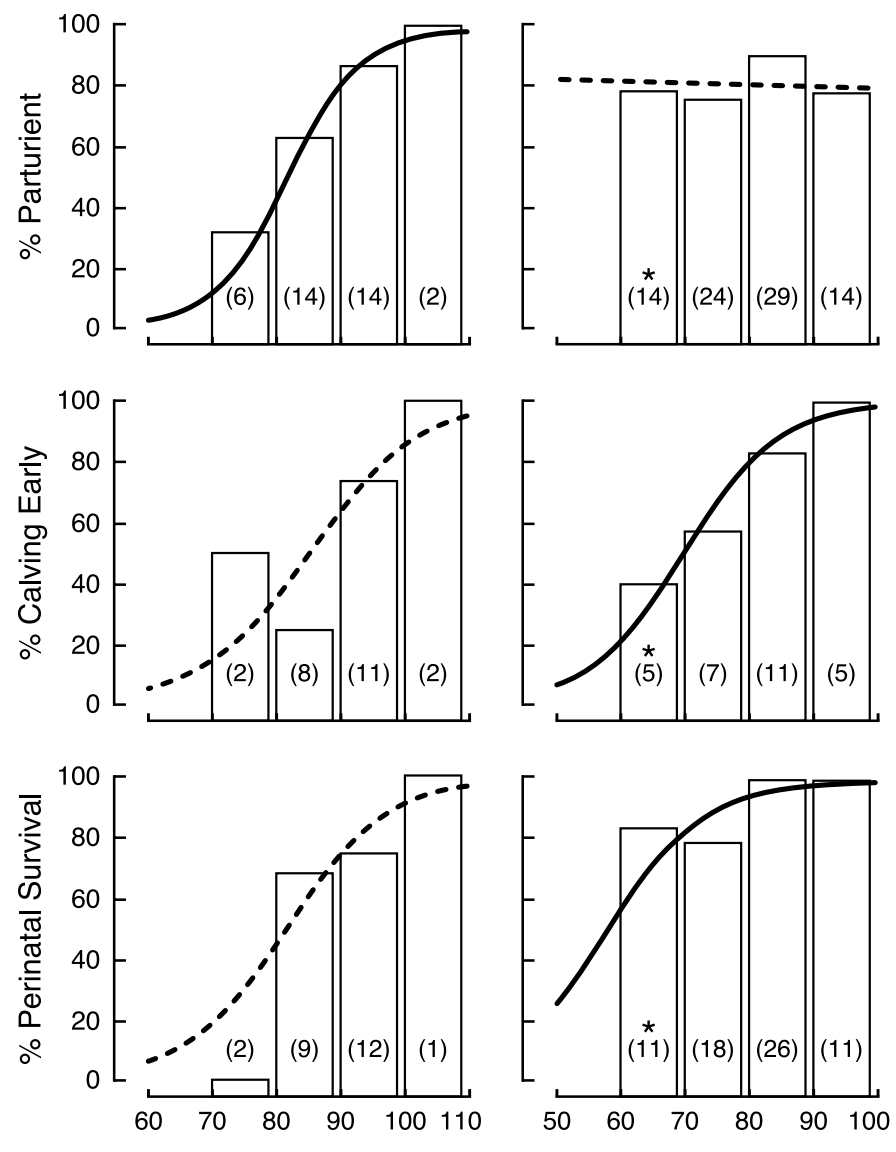

Autumn Body Weight $(\mathrm{kg})$

FIG. 8. Logistic regressions of parturition rate, incidence of early calving (on or before 7 June), and perinatal calf survival ( $>$ two days postpartum) on autumn and summer body weights of female caribou, Central Arctic Herd, Alaska, 1987-91. Solid lines are significant at $p<0.05$. The empirical percentages are shown at arbitrary $10 \mathrm{~kg}$ intervals of body weight. Numbers in parentheses are sample sizes. *The weight category $60-70 \mathrm{~kg}$ includes one female weighing $57 \mathrm{~kg}$ (Cameron et al., 1993; reprinted with permission from the Canadian Journal of Zoology).

shifted their concentrated calving area into habitats with lower plant biomass $(p<0.001)$ (Wolfe, 2000). In contrast, forage biomass remained constant $(p=0.23)$ within concentrated calving areas east of the Sagavanirktok River, where no development was present (Wolfe, 2000). Repeated use of lower-quality calving habitats may reduce forage intake by females to the west. Likewise, impaired summer movements between insect-relief habitat and inland feeding areas could depress energy balance (Smith, 1996) and, hence, rates of weight gain.

Indeed, several data sets suggest reduced nutritional status and fecundity of radio-collared females exposed to oil development west of the Sagavanirktok River. Estimates of July and October body weights, over-summer weight gain, the incidence of two pregnancies in successive years, and perinatal calf survival all tended to be lower for females to the west than for those under disturbance-free conditions to the east, although individual differences were not significant at the $95 \%$ confidence level (Cameron et al., 1992a). In a more recent analysis of data for 1988-94, however, the mean parturition rate of

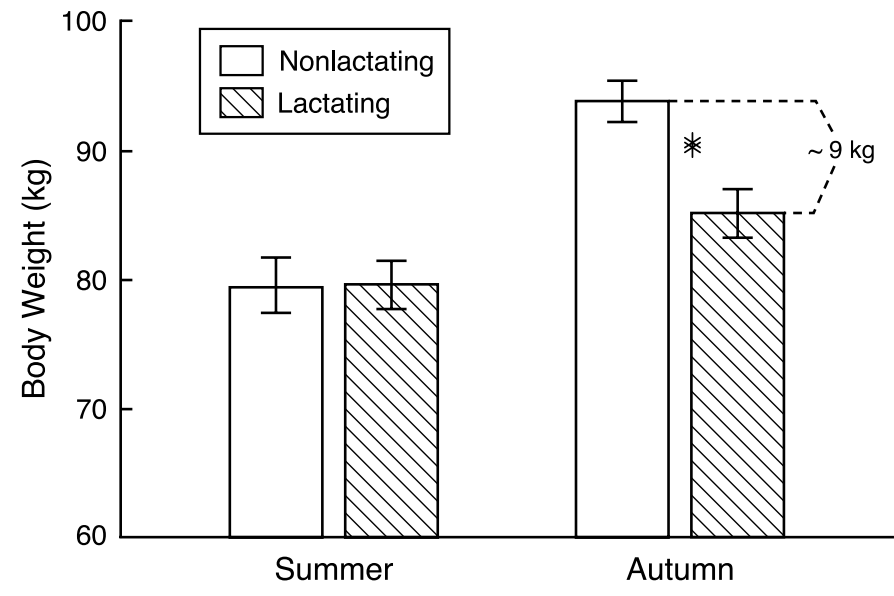

FIG. 9. Mean (SE) body weights of lactating $(n=23)$ and nonlactating $(n=23)$ female caribou in summer (July) and autumn (October), Central Arctic Herd, Alaska, 1988-91. *Difference is significant at $p<0.001$ (Cameron and White, 1996).

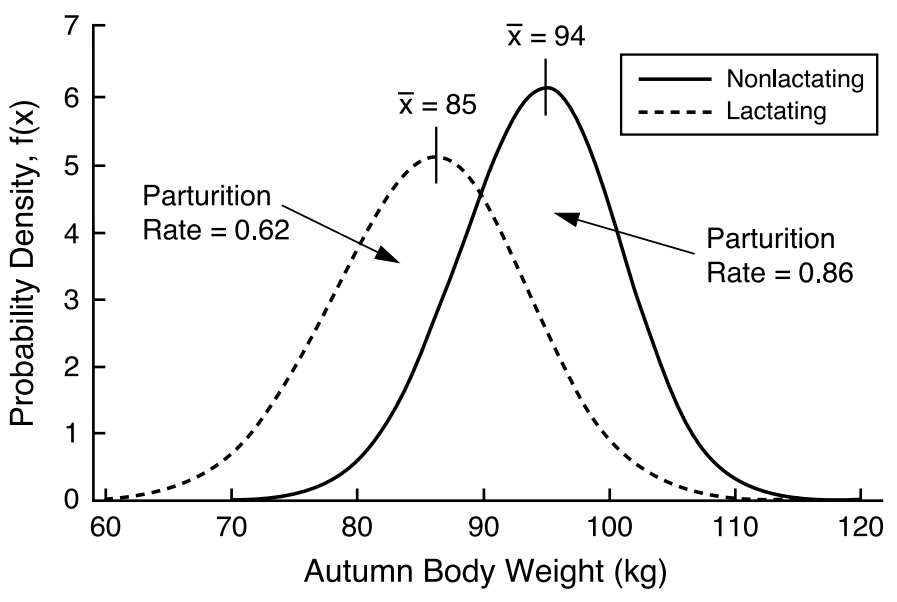

FIG. 10. Distributions of observed autumn (October) body weights for lactating and nonlactating female caribou, Central Arctic Herd, Alaska, 1988-91. The associated parturition rates are integrated estimates derived from the logistic model (Fig. 8) (Cameron and White, 1996).

females west of the Sagavanirktok River was $64 \%$ compared with $83 \%$ for females to the east ( $p=0.003$, Table 1 ) (Cameron, 1995). Corresponding frequencies of reproductive pauses (Cameron, 1994; Cameron and Ver Hoef, 1994 ) were $36 \%$ to the west of the river (26 of 73 observations) and $19 \%$ to the east ( 12 of 64 observations) $(p<0.02$, t-test, ratio method), or approximately one pause every three and five years, respectively (Cameron, 1995). With the opening of the Badami production unit east of the Sagavanirktok River in 1996, the undisturbed status of that area was compromised, rendering further comparisons problematic.

The key constraint on reproduction is lactation: it exacts a substantial cost on summer weight gain, which in turn influences the probability of conceiving that autumn. During 1988-91, weights of all lactating CAH females sampled averaged $9 \mathrm{~kg}$ less than those of nonlactating females (Fig. 9), resulting in a projected $28 \%$ reduction in parturition rate (Fig. 10). Lower parturition rates of 
TABLE 1. Parturition status of 43 radio-collared female caribou, ${ }^{1}$ Central Arctic Herd, west and east of the Sagavanirktok River, ${ }^{2}$ Alaska, 1988-94. The west side included the Prudhoe Bay oil field complex and Kuparuk Development Area (Fig. 1); the east side had no petroleum-related infrastructure (data from Cameron, 1995).

\begin{tabular}{lccrrr}
\hline \hline & \multicolumn{5}{c}{$\%$ Parturient $(\mathrm{n})$} \\
\cline { 2 - 6 } Year & \multicolumn{3}{c}{ West } & \multicolumn{2}{c}{ East } \\
\hline 1988 & 72.7 & $(11)$ & 100.0 & $(8)$ \\
1989 & 53.8 & $(13)$ & 77.8 & $(9)$ \\
1990 & 83.3 & $(12)$ & 100.0 & $(7)$ \\
1991 & 45.5 & $(11)$ & 75.0 & $(12)$ \\
1992 & 72.7 & $(11)$ & 75.0 & $(12)$ \\
1993 & 55.6 & $(9)$ & 62.5 & $(8)$ \\
1994 & 66.7 & $(6)$ & 87.5 & $(8)$ \\
Mean parturition rate, $\%^{3}$ & $64.3 \pm 5.0$ & $82.5 \pm 5.3$ \\
\hline \hline
\end{tabular}

${ }^{1}$ All sexually mature.

${ }^{2}$ Individual locations consistently west or east for $2-7$ years during the calving period.

${ }^{3}$ t-test, paired comparisons, $p=0.003$.

females west of the Sagavanirktok River during 1988-94 (Table 1) may reflect a failure to compensate for the metabolic burden of milk production (i.e., through increased forage intake or reduced energy expenditure). The result is consistently poorer condition in autumn and, hence, more frequent reproductive pauses, which contribute to a decline in calf production of the herd (Fig. 2).

Yet the degree to which lactation constrains weight gain does vary. An increase in net calf production during 1996 2000 (Fig. 2) suggests the prevalence of forage and insect conditions that enhanced growth and fattening, despite the demands of milk production and the presence of industrial activity.

\section{CONCLUSIONS}

Anthropogenic effects on caribou must be identified and assessed within the framework of a variable natural environment. Favorable foraging and insect conditions would attenuate the consequences of disturbance-induced changes in the quality of habitats occupied. Conversely, adverse conditions would exacerbate those same types of consequences (e.g., NRC, 2003:114-115). Unless analyses are based on multiyear observations of marked individuals and incorporate comparative data on an undisturbed control or reference group, conclusions will be equivocal at best. For example, absent a valid baseline, net growth of the CAH (Fig. 2) is no better evidence of compatibility with development than a net decline would be evidence of a conflict.

The crucial consideration for the future of the $\mathrm{CAH}$ and other Arctic caribou herds is whether changes in distribution associated with surface development, by depressing reproduction or survival, will either retard an increase in herd size or accelerate a decrease. Our data, in fact, indicate that productivity can and will decline if the cumulative loss of preferred habitat, when superimposed on natural forces, is sufficient to compromise nutrition.

\section{ACKNOWLEDGEMENTS}

Base funding was provided by Federal Aid in Wildlife Restoration and the Division of Wildlife Conservation, Alaska Department of Fish and Game. Supplemental support was provided by the Alaska Fish and Wildlife Research Center, U.S. Fish and Wildlife Service; Division of Habitat and Division of Subsistence, Alaska Department of Fish and Game; Institute of Arctic Biology, University of Alaska Fairbanks; ARCO Alaska, Inc.; EXXON Co. U.S.A.; SOHIO Petroleum Co.; CONOCO, Inc.; Continental Pipeline Co.; and the Alaska Department of Transportation and Public Facilities.

For analytical advice and technical assistance, we thank M.M. Billington, D.A. Borchert, K. Butters, G.M. Carroll, R.A. Caulfield, J.R. Dau, R.A. DeLong, S.G. Fancy, R.K. Friedrich, K.L. Gerhart, C.S. Gewin, H.N. Golden, R.G. Hunter, N. Ihlenfeldt, K. Jouppi, E.A. Lenart, J.A.K. Maier, T.R. McCabe, L.A. McCarthy, L.M. McManus, D.C. Miller, S. Pedersen, D.J. Reed, J.W. Schoen, M.D. Smith, R.T. Shideler, P. Valkenburg, J.M. Ver Hoef, N.E. Walsh, K.R. Whitten, J.F. Winters, and S.A. Wolfe. S.G. Fancy and two anonymous reviewers offered helpful comments and suggestions. An earlier version of this paper appeared as a section in a U.S. Geological Survey technical report (Cameron et al., 2002).

We dedicate this review to the memory of Ronald M. Warbelow, who died in 1995 after a long battle with cancer. Equally skilled at the controls of a helicopter or a fixed-wing aircraft, Ron was instrumental in the success of caribou capture and survey programs in the late 1980s and early 1990s. His friendship and enthusiastic participation will not be forgotten.

\section{REFERENCES}

ADAMCZEWSKI, J.Z., GATES, C.C.,HUDSON, R.J., and PRICE, M.A. 1987. Seasonal changes in body composition of mature female caribou and calves (Rangifer tarandus groenlandicus) on an Arctic island with limited winter resources. Canadian Journal of Zoology 65:1149-1157.

CAMERON, R.D. 1994. Reproductive pauses by female caribou. Journal of Mammalogy 75:10-13.

-1995. Can petroleum development depress the productivity of Arctic caribou? Paper presented at the 2nd International Arctic Ungulate Conference, 13-17 August 1995, Fairbanks, Alaska.

CAMERON, R.D., and VER HOEF, J.M. 1994. Predicting parturition rate of caribou from autumn body mass. Journal of Wildlife Management 58:674-679.

CAMERON, R.D., and WHITE, R.G. 1996. Importance of summer weight gain to the reproductive success of caribou in Arctic Alaska (Abstract only). Rangifer, Special Issue 9:397.

CAMERON, R.D., and WHITTEN, K.R. 1980. Influence of the trans-Alaska pipeline corridor on the local distribution of caribou. In: Reimers, E., Gaare, E., and Skjenneberg, S., eds. Proceedings of the Second International Reindeer/Caribou Symposium, Roros, 
Norway. Trondheim, Norway: Direktoratet for vilt og ferskvannsfisk. 475-484.

CAMERON, R.D., WHITTEN, K.R., SMITH, W.T., and ROBY, D.D. 1979. Caribou distribution and group composition associated with construction of the trans-Alaska pipeline. Canadian Field-Naturalist 93:155-162.

CAMERON, R.D., FANCY, S.G., and SMITH, W.T. 1992a. Reproductive performance of caribou in relation to habitat availability and quality. In: McCabe, T.R., Griffith, B., Walsh, N.E., and Young, D.D., eds. Terrestrial research: 1002 AreaArctic National Wildlife Refuge, interim report, 1988-90. Anchorage, Alaska: U.S. Fish and Wildlife Service. 67-78.

CAMERON, R.D., REED, D.J., DAU, J.R., and SMITH, W.T. 1992b. Redistribution of calving caribou in response to oil field development on the Arctic Slope of Alaska. Arctic 45(4): $338-342$.

CAMERON, R.D., SMITH, W.T., FANCY, S.G., GERHART, K.L., and WHITE, R.G. 1993. Calving success of female caribou in relation to body weight. Canadian Journal of Zoology 71: 480-486.

CAMERON, R.D., LENART, E.A., REED, D.J., WHITTEN, K.R., and SMITH, W.T. 1995. Abundance and movements of caribou in the oil field complex near Prudhoe Bay, Alaska. Rangifer $15: 3-7$.

CAMERON, R.D., RUSSELL, D.E., GERHART, K.L., WHITE, R.G., and VER HOEF, J.M. 2000. A model for predicting the parturition status of Arctic caribou. Rangifer, Special Issue 12: $1-3$.

CAMERON, R.D., SMITH, W.T., WHITE, R.G., and GRIFFITH, B. 2002. The Central Arctic caribou herd. In: Douglas, D.C., Reynolds, P.E., and Rhode, E.B., eds. Arctic Refuge coastal plain terrestrial wildlife research summaries. U.S. Geological Survey, Biological Resources Division, Biological Science Report USGS/BRD/BSR-2002-0001. 38-45.

CHILD, K.N. 1973. The reactions of barren-ground caribou (Rangifer tarandus granti) to simulated pipeline and pipeline crossing structures at Prudhoe Bay, Alaska. Completion Report, Fairbanks, Alaska: Alaska Cooperative Wildlife Research Unit, University of Alaska.

CLOUGH, N.K., PATTON, P.C., and CHRISTIANSEN, A.C., eds. 1987. Arctic National Wildlife Refuge, Alaska, coastal plain resource assessment. Report and recommendation to the Congress of the United States and final legislative environmental impact statement. Washington D.C.: U.S. Fish and Wildlife Service, U.S. Geological Survey, and Bureau of Land Management.

CRONIN, M.A., AMSTRUP, S.C., DURNER, G.M., NOEL, L.E., McDONALD, T.L., and BALLARD, W.B. 1998. Caribou distribution during the post-calving period in relation to infrastructure in the Prudhoe Bay oil field, Alaska. Arctic 51(2):85-93.

CURATOLO, J.A., and MURPHY, S.M. 1986. The effects of pipelines, roads, and traffic on movements of caribou, Rangifer tarandus. Canadian Field-Naturalist 100:218-224.

DAU, J.R. 1986. Distribution and behavior of barren-ground caribou in relation to weather and parasitic insects. M.S. Thesis, University of Alaska Fairbanks. 149 p.
DAU, J.R., and CAMERON, R.D. 1986. Effects of a road system on caribou distribution during calving. Rangifer, Special Issue $1: 95-101$.

DAUPHINÉ, T.C., Jr. 1976. Biology of the Kaminuriak population of barren-ground caribou. Part 4: Growth, reproduction, and energy reserves. Canadian Wildlife Service Report Series 38.

ELISON, G.W., RAPPOPORT, A.G., and REID, G.M., eds. 1986. Report of the Caribou Impact Analysis Workshop, Arctic National Wildlife Refuge, 19-20 November 1985. Fairbanks, Alaska: U.S. Fish and Wildlife Service.

ELORANTA, E., and NIEMINEN, M. 1986. Calving of the experimental reindeer herd in Kaamanen during 1970-85. Rangifer, Special Issue 1:115-121.

GERHART, K.L., RUSSELL, D.E., VAN DE WETERING, D., WHITE, R.G., and CAMERON, R.D. 1997. Pregnancy of adult caribou (Rangifer tarandus): Evidence for lactational infertility. Journal of Zoology 242:17-30.

HAUKIOJA, E., and SALOVAARA, R. 1978. Summer weight of reindeer (Rangifer tarandus) calves and its importance for their future survival. Report of the Kevo Subarctic Research Station $14: 1-4$.

LENVIK, D., GRANEFJELL, O., and TAMNES, J. 1988. Selection strategy in domestic reindeer: 5. Pregnancy in domestic reindeer in Trondelag County, Norway. Norsk Landbruksforsk 2: $151-161$.

MURPHY, S.M. 1988. Caribou behavior and movements in the Kuparuk oil field: Implications for energetic and impact analyses. Proceedings of the Third North American Caribou Workshop. Alaska Department of Fish and Game, Juneau, Alaska. Wildlife Technical Bulletin 8:196-210.

MURPHY, S.M., and CURATOLO, J.A. 1987. Activity budgets and movement rates of caribou encountering pipelines, roads, and traffic in northern Alaska. Canadian Journal of Zoology 65:122- 128 .

NELLEMANN, C., and CAMERON, R.D. 1996. Effects of petroleum development on terrain preferences of calving caribou. Arctic 49(1):23-28.

1998. Cumulative impacts of an evolving oil-field complex on the distribution of calving caribou. Canadian Journal of Zoology 76:1425-1430.

NRC (NATIONAL RESEARCH COUNCIL). 2003. Cumulative effects of oil and gas activities on Alaska's North Slope. Washington D.C.: The National Academies Press.

REIMERS, E. 1983. Reproduction in wild reindeer in Norway. Canadian Journal of Zoology 61:211-217.

ROGNMO, A., MARKUSSEN, K.A., JACOBSEN, E., GRAV, H.J., and BLIX, A.S. 1983. Effects of improved nutrition in pregnant reindeer on milk quality, calf birth weight, growth, and mortality. Rangifer 3:10-18.

RUSSELL, D.E., KOFINAS, G., and GRIFFITH, B. 2002. BarrenGround Caribou Calving Ground Workshop: Report of proceedings. Canadian Wildlife Service Technical Report Series 390.

SKOGLAND, T. 1984. The effects of food and maternal conditions on fetal growth and size in wild reindeer. Rangifer 4:39-46.

SMITH, M.D. 1996. Distribution, abundance, and quality of forage within the summer range of the Central Arctic caribou herd. M.S. Thesis, University of Alaska Fairbanks. 43 p. 
SMITH, W.T., and CAMERON, R.D. 1983. Responses of caribou to industrial development on Alaska's Arctic Slope. Acta Zoologica Fennica 175:43-45. . 1985. Reactions of large groups of caribou to a pipeline corridor on the arctic coastal plain of Alaska. Arctic 38(1): $53-57$.

1992. Caribou responses to development infrastructures and mitigation measures implemented in the Central Arctic Region. In: McCabe, T.R., Griffith, B., Walsh, N.E., and Young, D.D., eds. Terrestrial research: 1002 Area-Arctic National Wildlife Refuge, interim report, 1988-90. Anchorage, Alaska: U.S. Fish and Wildlife Service. 79-86.

SMITH, W.T., CAMERON, R.D., and REED, D.J. 1994. Distribution and movements of caribou in relation to roads and pipelines, Kuparuk Development Area, 1978-90. Wildlife Technical Bulletin 12. Juneau: Alaska Department of Fish and Game.

THOMAS, D.C. 1982. The relationship between fertility and fat reserves of Peary caribou. Canadian Journal of Zoology 60: 597-602.

THOMAS, D.C., and KILIAAN, H.P.L. 1998. Fire-caribou relationships. II: Fecundity and physical condition in the Beverly herd. Canadian Wildlife Service Technical Report Series 310.
WHITE, R.G. 1983. Foraging patterns and their multiplier effects on productivity of northern ungulates. Oikos 40:377-384.

WHITE, R.G., THOMSON, B.R., SKOGLAND, T., PERSON, S.J., RUSSELL, D.E., HOLLEMAN, D.F., and LUICK, J.R. 1975. Ecology of caribou at Prudhoe Bay, Alaska. In: Brown, J., ed. Ecological investigations of the tundra biome in the Prudhoe Bay region, Alaska. Biological Papers of the University of Alaska, Special Report 2. 151-201.

WHITTEN, K.R., and CAMERON, R.D. 1983a. Movements of collared caribou, Rangifer tarandus, in relation to petroleum development on the Arctic Slope of Alaska. Canadian FieldNaturalist 97:143-146.

1983b. Population dynamics of the Central Arctic Herd, 1975 - 81. Acta Zoologica Fennica 175:159-161.

- 1985. Distribution of caribou calving in relation to the Prudhoe Bay oil field. In: Martell, A., and Russell, D., eds. Proceedings of the First North American Caribou Workshop, Whitehorse, Yukon Territory, 1983. Special Publications. Ottawa, Ontario: Canadian Wildlife Service. 35-39.

WOLFE, S.A. 2000. Habitat selection by calving caribou of the Central Arctic Herd, 1980-95. M.S. Thesis, University of Alaska, Fairbanks, Alaska. 83 p. 